\title{
Treatment of hemopericardium caused by mitral balloon valvuloplasty with activated factor VIl: a case report
}

\author{
Jeremy Steele ${ }^{1}$, Igor Mamkin², Berhane Worku ${ }^{3}$ and losif Gulkarov ${ }^{3 *}$
}

\begin{abstract}
Introduction: The use of mitral balloon valvuloplasty as a percutaneous intervention for mitral stenosis has been shown to be efficacious. Cardiac tamponade is a rare but serious complication of this procedure. Despite the low incidence of this event, cardiac tamponade is well-reported in the literature. The management strategy of this complication involves pericardial drainage and correction of coagulopathy, followed by surgical exploration if these interventions fail. With this case report, we demonstrate the successful application of activated factor VII in the management of bleeding after balloon valvuloplasty that persisted despite the standard treatments described above.
\end{abstract}

Case presentation: Our patient was a 31-year-old Yemenite man with no significant past medical history, who presented with progressively worsening dyspnea on exertion and limited functional capacity over the last few years. A transesophageal echocardiogram revealed severe mitral stenosis, which was treated with a mitral valve valvuloplasty. The procedure was complicated by significant mediastinal bleeding that did not respond to routine maneuvers, which included pericardiocentesis and correction of coagulopathy. Our patient was evaluated for surgical intervention but responded to treatment with activated factor VII.

Conclusion: Factor VII may be used in the treatment of refractory mediastinal bleeding secondary to mitral valvuloplasty prior to attempting surgical repair, and therefore may spare the patient the morbidity associated with surgery.

Keywords: Complications and management, Factor VIla, Hemopericardium, Mediastinal bleeding, Mitral balloon valvuloplasty

\section{Introduction}

Cardiac perforation during cardiac catheterization procedures is very rare and only about one third result in some degree of cardiac tamponade [1-10]. The procedures responsible for the highest incidence of cardiac tamponade include percutaneous mitral valvuloplasty [11]. The incidence of cardiac tamponade during mitral balloon valvuloplasty (MBV) is reported to be between $1 \%$ and $9 \%$ [1-7]. The presence of cardiac tamponade is an absolute indication for emergent pericardial drainage and can be performed by either pericardiocentesis or surgical pericardiotomy $[11,12]$. Additional interventions that should be considered include correction of coagulopathy

\footnotetext{
* Correspondence: iog9001@nyp.org

${ }^{3}$ Department of Cardiothoracic Surgery, New York Methodist Hospital, 506 Sixth Street, Miner 3, Brooklyn, NY 11215, USA

Full list of author information is available at the end of the article
}

with protamine, fresh frozen plasma, cryoprecipitate and platelets, and resuscitation with blood transfusions and intravenous fluids $[1,8,11,13,14]$. These interventions are often successful in controlling bleeding within several hours [8]. Intractable bleeding requires a sternotomy. In this report, we describe the successful application of activated factor VII (aFVII) in the management of persistent bleeding during MBV, thereby avoiding a sternotomy and the associated morbidity of this approach.

\section{Case presentation}

Our patient was a 31-year-old Yemenite man, with no significant past medical or surgical history, who was not on anticoagulants. He presented with progressively worsening dyspnea on exertion and limited functional capacity over the last few years. His physical examination was significant for an opening snap, a grade 2-3/6 diastolic murmur and 
a 1/6 holosystolic murmur. Laboratory parameters were significant for a normal coagulation profile. Our patient's electrocardiogram showed left atrial enlargement and no evidence of ventricular hypertrophy. A transesophageal echocardiogram revealed normal left ventricular systolic function with an ejection fraction of $60 \%$ and left atrial dilation. The mitral valve was minimally calcified with mild thickening limited to the leaflet margin without chordal involvement. Characteristic echocardiographic features of rheumatic mitral stenosis were present with a Wilkins score of three [15]. The mean mitral gradient was $11 \mathrm{mmHg}$ and the valve area was $1.1 \mathrm{~cm}^{2}$. Given our patient's age, New York Heart Association Class III symptoms and mitral valve morphology, he was deemed to be a good candidate for MBV. Heparin was administered with an activated clotting time measured as 272 seconds. Valvuloplasty was performed utilizing a transeptal approach with a $26 \mathrm{~mm}$ Inoueballoon catheter.

At the end of the procedure, our patient was noted to have an effusion on the echocardiogram, with features of cardiac tamponade. He was otherwise hemodynamically stable. The effusion was treated with emergent pericardiocentesis and a pericardial catheter was left for continuous drainage. Pericardial catheter output ceased after the drainage of approximately one liter of blood. An hour after arrival to the intensive care unit, a pericardial effusion was noted again on surveillance transthoracic echocardiography. Our patient drained $350 \mathrm{ml} / \mathrm{h}$ of bright red blood for the next three hours despite a normal coagulation profile. During this time, his presumed coagulopathy was corrected with protamine ( $25 \mathrm{mg}$ intravenously), two units of fresh frozen plasma, two single donor platelets and six units of cryoprecipitate, and his coagulation profile then rechecked. Complete evacuation of his pericardial sac was verified hourly with surveillance transthoracic echocardiography. Despite a normal coagulation profile the bleeding persisted, with its exact site of origin unknown. Our patient was warm, had normal acid-base status, and remained hemodynamically stable throughout, yet an additional 350cc of blood was drained within the next hour. At that time, the decision was made to administer $4.8 \mathrm{mg}$ $(70 \mu \mathrm{g} / \mathrm{kg})$ of aFVII intravenously over two minutes. Drainage from the pericardial tube almost immediately ceased. Transesophageal echocardiography revealed resolution of the hemopericardium.

Our patient is doing well two years after the MBV. He has a mitral valve gradient of $4 \mathrm{mmHg}$ and he has functionally improved to New York Heart Association Class I. His coagulopathy work-up was negative.

\section{Discussion}

To the best of our knowledge, this is the first report of successful use of aFVII in the management of intractable bleeding after MBV despite maximum medical therapy.
An algorithm for management of postprocedural mediastinal bleeding usually involves placement of mediastinal drainage catheter and correction of coagulopathy. If bleeding is refractory and/or the patient becomes hemodynamically unstable, surgical intervention should be considered. In our case, our patient was hemodynamically stable yet had persistent bleeding that did not respond to the correction of coagulopathy and mediastinal drainage. Given our growing experience with use of aFVII in cardiac surgery and the relative stability of our patient, we decided to administer aFVII, with plans for transport to the operating room if bleeding did not subside. Drainage from the mediastinal tube almost immediately ceased after aFVII was administered.

Current indications for the use of aFVII are congenital factor VII deficiency, hemophilia and Glanzmann thrombasthenia. Despite its high cost (US\$1 per microgram), there has recently been an influx of research citing increased off-label use of aFVII in the management of intractable bleeding, in not only cardiac surgery [16] but also intracranial hemorrhage, trauma, liver transplantation and prostatectomy [17]. Factor VII plays a very important role in the initiation of coagulation by combining with tissue factor (TF). Factor VII is constantly circulating in the bloodstream and is not exposed to TF until there is an injury to a blood vessel [16]. The activity of both factor VII and TF are required to initiate coagulation and this is accomplished when the TF/factor VIIa complex works in conjunction with the factor VIII/IX complex to activate factor $\mathrm{X}$, which in turn is required for thrombin generation [16]. It has been shown that at certain dosing levels aFVII can bypass the requirement of factors VIII and IX and independently activate factor X. Additionally, it has been shown to normalize prothrombin times in patients with thrombocytopenia by improving platelet function [16]. The end effect is a thrombin burst and platelet activation that leads to a more effective platelet plug formation.

\section{Conclusion}

aFVII may be considered prior to surgical intervention in hemodynamically stable patients in the context of mediastinal bleeding refractory to medical therapy after MBV.

\section{Consent}

Written informed consent was obtained from the patient for publication of this case report. A copy of the written consent is available for review by the Editor-in-Chief of this journal.

\section{Abbreviations}

aFVII: Activated factor VII; MBV: Mitral balloon valvuloplasty; TF: Tissue factor.

\section{Competing interests}

The authors declare that they have no competing interests. 


\section{Authors' contributions}

IS was involved in drafting the manuscript and revising it critically for important intellectual content. IM made substantial contributions to conception and design, and acquisition of data. BW was involved in revising the manuscript critically for important intellectual content. IG made substantial contributions to conception and design; was involved in drafting the manuscript and revising it critically for important intellectual content; and gave final approval of the version to be published. All authors read and approved the final manuscript.

\section{Author details}

'Department of Pediatrics, SUNY Upstate Medical University Center, Golisano Children's Hospital, 750 East Adams Street, Syracuse, NY 13210, USA

2Division of Cardiology New York Methodist Hospital, 506 Sixth Street, Miner 3, Brooklyn, NY 11215, USA. ${ }^{3}$ Department of Cardiothoracic Surgery, New York Methodist Hospital, 506 Sixth Street, Miner 3, Brooklyn, NY 11215, USA.

Received: 29 March 2013 Accepted: 25 November 2013

Published: 28 January 2014

\section{References}

1. Pan M, Medina A, Suárez de Lezo J, Hernández E, Romero M, Pavlovic D, Melián F, Segura J, Román M, Montero A, Morales J, Franco M, Montijano A, Valles F: Cardiac tamponade complicating mitral balloon valvuloplasty. Am J Cardiol 1991, 68(8):802-805.

2. Vahanian A, Michel PL, Cormier B, Vitoux B, Cazaux P, Roger V: Mitral valvuloplasty. In Interventional Cardiology. Edited by Meier B. Toronto: Hogrefe \& Huber; 1990:309-325.

3. Sancho M, Medina A, SudrezdeLezo J, Hernandez E, Pan M, Coello I, Romero M, Melian F, Segura J, Jimenez F, Vivancos R: Factors influencing progression of mitral regurgitation after transarterial balloon valvuloplasty for mitral stenosis. Am J Cardiol 1990, 66:737-740.

4. Rocha P, Berland J, Mechmeche R, Gamra H, Boussadia H, Gerber L, Grigera F, Letac B: Percutaneous mitral valvuloplasty using balloon catheterization. Immediate results in 80 cases. Ara Bras Cardiol 1989, 52:253-258.

5. Al Douri M, Shafi T, Al Khudairi D, Al Bokhari E, Black L, Akinwale N, Osman Musa M, Al Homaidhi A, Al Fagih M, Borum AR: Effect of the administration of recombinant activated factor VII (rFVIla; NovoSeven) in the management of severe uncontrolled bleeding in patients undergoing heart valve replacement surgery. Blood Coagul Fibrinolysis 2000, 11 (Suppl 1):S121-S127.

6. Ruiz CE, Allen JW, Lao FYK: Percutaneous double balloon valvotomy for severe rheumatic mitral stenosis. Am J Cardio/ 1990, 65:473-477.

7. Inoue K, Hung JS: Percutaneous mitral commissurotomy: the Far East experience. In Textbook of Interventional Cardiology. Edited by Topol EJ. Philadelphia: WB Saunders; 1990:887-899.

8. Friedrich SP, Berman AD, Baim DS, Diver DJ: Myocardial perforation in the cardiac catheterization laboratory: incidence, presentation, diagnosis, and management. Cathet Cardiovasc Diagn 1994, 32(2):99-107.

9. Braunwald E, Gorlin R, Mclntosh HD, Ross RS, Rudolph AM, Swan HJ: Cooperative study on cardiac catheterization. Summary. Circulation 1968, 37(5 Suppl):III93-101.

10. Gorlin R: 7. Circulation 1968, 37(Suppl. III):36-38.

11. Seferović PM, Ristić AD, Imazio M, Maksimović R, Simeunović D, Trinchero R, Pankuweit S, Maisch B: Management strategies in pericardial emergencies. Herz 2006, 31(9):891-900.

12. Maisch B, Seferovic PM, Ristic AD, Erbel R, Rienmuller R, Adler $Y$, Tomkowsk WZ, Thiene G, Yacoub MH, Task Force on the Diagnosis and Management of Pericardial Diseases of the European Society of Cardiology: Guidelines on the diagnosis and management of pericardial diseases. Executive summary. Eur Heart J 2004, 25:587-610.

13. Ruiz CE, Bansal RC: Percutaneous closure of a left ventricular perforation post balloon mitral valvotomy. Catheter Cardiovasc Interv 1999, 48(1):78-83.

14. Spodick DH: Acute cardiac tamponade. N Engl J Med 2003, 349:684-690.

15. Wilkins GT, Weyman AE, Abascal VM, Block PC, Palacios IF: Percutaneous dilatation of the mitral valve: an analysis of echocardiographic variables related to outcome and the mechanism of dilatation. Br Heart J 1988 60:299-308.

16. Hermann HC, Kleaveland P, Hill JA, Cowley MJ, Margolis JR, Nocero MA, Zalewski A, Pepine CJ, for the M-Heart Group: The M-Heart Percutaneous
Balloon Mitral Valvuloplasty Registry: initial results and early follow-up. J Am Coll Cardiol 1990, 15:1221-1226.

17. Yank V, Tuohy CV, Logan AC, Bravata DM, Staudenmayer K, Eisenhut R, Sundaram V, McMahon D, Olkin I, McDonald KM, Owens DK, Stafford RS: Systematic review: benefits and harms of in-hospital use of recombinant factor VIla for off-label indications. Ann Intern Med 2011, 154(8):529-540.

doi:10.1186/1752-1947-8-33

Cite this article as: Steele et al.: Treatment of hemopericardium caused by mitral balloon valvuloplasty with activated factor VII: a case report. Journal of Medical Case Reports 2014 8:33.

\section{Submit your next manuscript to BioMed Central and take full advantage of:}

- Convenient online submission

- Thorough peer review

- No space constraints or color figure charges

- Immediate publication on acceptance

- Inclusion in PubMed, CAS, Scopus and Google Scholar

- Research which is freely available for redistribution

Submit your manuscript at www.biomedcentral.com/submit
C) Biomed Central 